\section{Characteristics of Soy Corn Yogurt}

\section{Angelia Dwi Lestiyani ${ }^{1}$, Thomas Indarto Putut Suseno ${ }^{1}$ and Ignatius Srianta ${ }^{1 *}$}

\begin{abstract}
This research was to study the characteristics of soy corn yogurt, a new developed nutritious food product. Soy corn yogurt was produced by fermentation of soy corn milk using Streptococcus thermophilus and Lactobacillus bulgaricus, at various soybean and sweet corn ratios of 90:10; 80:20; 70:30; $60: 40$ and 50:50 (w/w) Total lactic acid bacteria, $\mathrm{pH}$, total acidity, syneresis amartand preferences of appearance, texture, aroma and taste of the product were investigated. The results showed that the lactic acid bacteria grew well in the soy corn milk with final total lactic acid bacteria in a range of $6.26 \times 10^{10}$ to $1.46 \times 10^{11} \mathrm{cfu} / \mathrm{mL}$. Soy corn yogurt with soybean and sweet corn ratio of 50:50 was the highest preference scores. Aflatoxin $B_{1}, B_{2}, G_{1}$ and $G_{2}$ were not detected in the soy corn yogurt by HPLC with limit of dxdetection of $1 \mathrm{ppb}$ that reflected the soy corn yogurt is a safe food product.
\end{abstract}

\section{Keywords}

Soy corn yogurt; Sweet corn; Lactic acid bacteria; Characteristics; Aflatoxin

\section{Introduction}

Soy corn milk is a legume-based milk which produced by extraction of soybean and corn blend. Legume-based milks have been developed to overcome the problems of lactose intolerance and saturated fat of cow milk; and as relatively inexpensive protein sources. Combining soybean and corn create a nutritious soy corn milk [1-3]. Soy corn blending offers dual nutritional advantages in combating protein and vitamin A deficiency, improves the overall acceptability by both adults and children; and improves the digestability $[1,3,4]$. Concerning on the health issue on the corn based products which facing problem on aflatoxin contamination, Srianta et al. [5] developed low aflatoxin soy corn milk using sweet corn on the cob. The sweet corn does not seem to be affected by the aflatoxins contamination problem, as also reported by other researchers. Stoloff et al. [6] showed that the sweet corn did not contain aflatoxin in 263 samples and aflatoxins were only detected in 8 of 27 samples of sweet corn at a level below $4 \mathrm{ng} / \mathrm{g}$ and 1 sample contained of 5-10 ng/g [7]. The soy corn milk contained low level aflatoxin of $0.24 \mathrm{ng} / \mathrm{mL}$ [5].

The low aflatoxin soy corn milk is potential as a main ingredient of non dairy yogurt. Recently researchers develop non-dairy yogurt using plant material i.e. soymilk yogurt, corn yogurt, coconut yogurt and soy corn yogurt [8-11]. Lactobacillus bulgaricus and Streptococcus

*Corresponding author: Ignatius Srianta, Department of Food Technology, Widya Mandala Catholic University Surabaya, Jalan Dinoyo 42-44 Surabaya, Indonesia 60265, Tel: +6231 5678478; Fax: +6231 561081; Email: srianta_wm@yahoo.com

Received: September 30, 2013 Accepted: March 05, 2014 Published: March 10, 2014 thermophilus have been used as starter cultures to produce corn yogurt and soy corn yogurt $[9,11]$. Makanjuola [11] reported that the ratio of soy milk and yellow corn milk affect the characteristics of soy corn yogurt. have used those bacteria to produced soy corn yogurt.

This research was aimed to study the characteristics of soy corn yogurt at various soybean and sweet corn ratios. The characteristics are the total lactic acid bacteria, $\mathrm{pH}$, total acidity, syneresis and the preferences of appearance, texture, aroma and taste.

\section{Materials and Methods}

\section{Materials}

Soybean and sweet corn on the cob were obtained from local market in Surabaya, East Java, Indonesia. Lactobacillus bulgaricus FNCC 0041 and Streptococcus thermophilus FNCC 0040 were obtained from Food and Nutrition Culture Collection, Gadjah Mada University, Yogyakarta. All chemicals and media were purchased from local distributor.

\section{Soy corn milk processing}

Sorted soybean was soaked in water with ratio of soybean: water $=1: 4$ for 8 hours, then boiled for $30 \mathrm{~min}$. Sweet corn was steamed for 30 minutes then the grains were threshed out. Boiled soybean cotyledone and steamed sweet corn grain were mixed at ratio of $90: 10 ; 80: 20 ; 70: 30 ; 60: 40$ and 50:50, then added with water at ratio of $1: 3(\mathrm{w} / \mathrm{v})$. Extraction was carried out by grinding, boiling for 20 minutes and filtering. The filtrate was added by sugar of $7 \%$, xanthan gum of $0.03 \%$, and soy protein isolate of $2.5 \%$.

\section{Soy corn yogurt processing}

Figure 1 showed the flowchart of soy corn yogurt processing. Soy corn milk was boiled for 15 minutes and then cooled to $45^{\circ} \mathrm{C}$ and inoculated with $3 \%$ of yogurt starter culture (L. bulgaricus and $S$. thermophilus $=1: 1$ ) and incubated at $42^{\circ} \mathrm{C}$ for 7 hours. The soy corn yogurt was then analyzed of the total lactic acid bacteria, physicochemical properties ( $\mathrm{pH}$, total acidity and syneresis) and sensory properties (preference score of appearance, aroma, texture and taste).

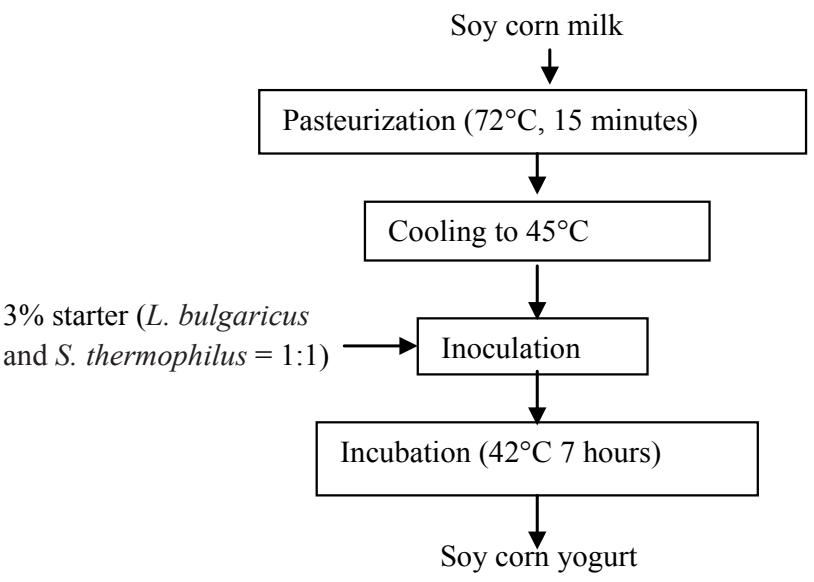

Figure 1: Flowchart of soy corn yogurt processing. 


\section{Determination of Total Lactic Acid Bacteria (LAB)}

$5 \mathrm{ml}$ of soy corn yogurt was mixed with $45 \mathrm{ml}$ of sterile peptone water $0.1 \%$ in an Erlenmeyer flask, as dilution of $10^{-1}$. Then $0.5 \mathrm{ml}$ of the mixture was aseptically transferred into $4.5 \mathrm{ml}$ of sterile peptone water $0.1 \%$ in a glass tube. Using separate sterile pipette, dilutions of $10^{-2}$ until $10^{-10}$ were also carried out with the same way to the dilution of $10^{-1}$. Pipette $1 \mathrm{ml}$ of each diluted solution of $10^{-6}$ until $10^{-10}$ into separate, duplicate, appropriately marked petri dishes. Add $15 \mathrm{ml}$ of de Man Rogosa Sharpe (MRS) agar (cooled to $50 \pm 1^{\circ} \mathrm{C}$ ) into each plate. The mixture was immediately mixed thoroughly and uniformly by alternate rotation and back-and-forth motion of plates on flat level surface. Let agar solidify and then incubate promptly for 48 hours at $37^{\circ} \mathrm{C}$. Count the colonies of lactic acid bacteria which grow on the medium.

\section{Measurement of $\mathrm{pH}$, Total acidity and Syneresis}

$\mathrm{pH}$ was measured by $\mathrm{pH}$ meter (Trans Instrument TI-2100). Total acidity was measured according to AOAC [12]. $10 \mathrm{ml}$ of soy corn yogurt was mixed with $100 \mathrm{ml}$ of distilled water and indicator phenolphthalein $1 \%$, and then titrated with $\mathrm{NaOH} 0.1 \mathrm{~N}$. Syneresis was measured according to Supavititpatana et al. [13] with modification. Sterile empty cup was weighed, filled up the cup with 50 $\mathrm{ml}$ of soy corn yogurt aseptically, incubated for 7 hours at $42^{\circ} \mathrm{C}$, and then let it stand at $4^{\circ} \mathrm{C}$ in a refrigerator for 24 hours, the liquid was separated from the solid and then the liquid was weighed.

\section{Aflatoxin analysis}

Aflatoxin analysis was done by High Performance Liquid Chromatography (HPLC) according to the method of Srianta et al. [5]. Soy corn yogurt was extracted and degreased by mixing $50 \mathrm{~mL}$ of sample with $50 \mathrm{~mL}$ of methanol and 1 gram of $\mathrm{NaCl}$, then filtered. The filtrate was added by $25 \mathrm{~mL}$ of hexane, followed by collecting the methanol phase. $4 \mathrm{~mL}$ of the methanol phase was diluted with $16 \mathrm{~mL}$ of Buffer Phosphate Saline and loaded into immunoaffinity column (IAC), then washed by passing $10 \mathrm{~mL}$ of distilled water and completed by flushing air into IAC to remove remaining water. After that, elution through IAC with $1 \mathrm{~mL}$ of methanol (first, incubated for 5 minutes) following with $1 \mathrm{~mL}$ of methanol at flowrate one drop per second. After that, $2 \mathrm{~mL}$ of obtained eluate was mixed with 50 $\mathrm{uL}$ of trifluoroacetic acid and $200 \mathrm{uL}$ of $\mathrm{n}$-hexane for derivatisation, then evaporated with stream of nitrogen gas, then reconstituted with $200 \mathrm{uL}$ of mobile phase. $20 \mathrm{uL}$ of aliquot was injected into HPLC column with below condition: HPLC column Octadesyl reversephase column ( $250 \mathrm{~mm}$ length $\mathrm{x} 4.6 \mathrm{~mm}$ i.d, $5 \mathrm{um}$ ), mobile phase acetonitrile/methanol/water:11/26/63) with flow rate of $0.75 \mathrm{~mL} /$

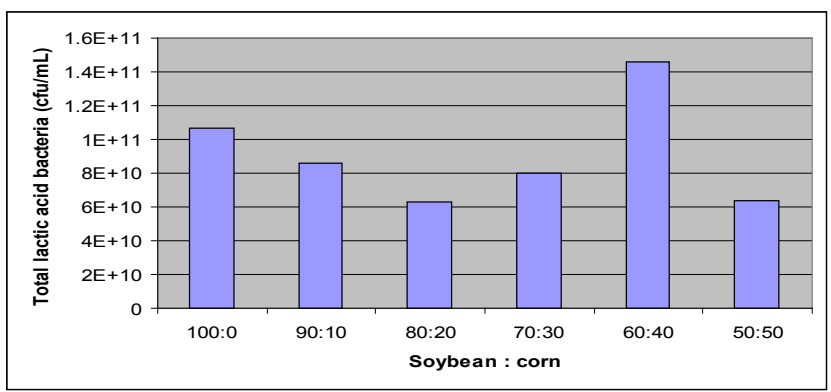

Figure 2: Total lactic acid bacteria of soy corn yogurt at different ratio of soybean and sweet corn. minute and fluorometer detector $\left(\lambda_{\text {ext }} 365 \mathrm{~nm}, \lambda_{\mathrm{em}} 435 \mathrm{~nm}\right)$. Aflatoxin $B_{1}, B_{2}, G_{1}$ and $G_{2}$ were used as standard.

\section{Sensory evaluation}

The sensory evaluation of the soy corn yogurt was done by 80 panelists who are familiar with soymilk and yogurt. Hedonic method was used with scale of one represent dislike extremely to seven represent like extremely. The panelists were requested to evaluate the appearance, aroma, texture and taste of the soy corn yogurt.

\section{Statistical Analysis}

The obtained data were analysed using Analysis of Varians (ANOVA) with $\alpha=5 \%$ and Duncan's Multiple Range Test (DMRT) with $\alpha=5 \%$.

\section{Results and Discussion \\ Total Lactic Acid Bacteria}

Total count of L. bulgaricus and S. thermophilus as starter culture in the soymilk medium were of $8.5 \times 10^{7}$ and $8.0 \times 10^{10} \mathrm{cfu} /$ $\mathrm{mL}$, respectively. Total $\mathrm{LAB}$ of the yogurt at the end of fermentation shown in Figure 2. Total LAB of soy corn yogurt in a range of $6.26 \times 10^{10}$ and $1.46 \times 10^{11} \mathrm{cfu} / \mathrm{mL}$, which statistically the total LAB were not significantly different at the various ratios of soybean and sweet corn. It reflected that L. bulgaricus and S. thermophilus grew well in soy corn milk medium at the various ratios of soybean and sweet corn. Total LAB of soy corn yogurt were similar with total LAB of cow milk yogurt [14]. It showed that lactic acid bacteria can survive and grow well in soy corn milk as well as in dairy milk.

\section{Physicochemical characteristics}

Table 1 showed the result of physicochemical characteristics of soy corn yogurt at different ratio of soybean and sweet corn. $\mathrm{pH}$ of the soy corn yogurt in a range of 4.539 and 4.760; and the total acidity of $0.38 \%$ and $0.45 \%$. The $\mathrm{pH}$ values are similar to, but the total acidity are higher than those reported by Makanjuola [11]. The higher total acidity might be due to of higher LAB activity as the sweet corn contains higher sugar than the yellow corn. Higher ratio of sweet corn would decrease $\mathrm{pH}$ value and increase total acidity. This might be due to the fructose of the sweet corn can be used as substrate converted to lactic acid. Total acidity of soy corn yogurt was less than the dairy yogurt. This might be due to the different kind of substrate. Main substrate in dairy milk is lactose, but main substrate in soy corn milk are fructose and sucrose from sugar addition. S. thermophillus and $L$. bulgaricus has an ability to consume lactose and fructose and convert them into lactic acid via Embden-Meyerhof-Parnas (EMP) pathway, but $L$. bulgaricus unable to consume the sucrose into lactic acid via EMP pathway because the bacteria do not produce invertase [15].

Syneresis of the soy corn yogurt varied from $5.12 \%$ to $5.44 \%$ but

Table 1: Physicochemical characteristics of soy corn yogurt at different ratio of soybean and sweet corn.

\begin{tabular}{|l|l|l|l|}
\hline Soybean : sweet corn & $\mathrm{pH}$ & Total acidity (\%) & Syneresis (\%) \\
\hline $100: 0$ & $4.760 \pm 0.020 \mathrm{c}$ & $0.38 \pm 0.01 \mathrm{a}$ & $5.41 \pm 1.10 \mathrm{a}$ \\
\hline $90: 10$ & $4.681 \pm 0.071 \mathrm{~b}$ & $0.39 \pm 0.01 \mathrm{ab}$ & $5.24 \pm 1.61 \mathrm{a}$ \\
\hline $80: 20$ & $4.638 \pm 0.043 \mathrm{~b}$ & $0.40 \pm 0.02 \mathrm{~b}$ & $5.44 \pm 0.97 \mathrm{a}$ \\
\hline $70: 30$ & $4.582 \pm 0.005 \mathrm{a}$ & $0.42 \pm 0.01 \mathrm{c}$ & $5.38 \pm 1.26 \mathrm{a}$ \\
\hline $60: 40$ & $4.556 \pm 0.013 \mathrm{a}$ & $0.43 \pm 0.01 \mathrm{c}$ & $5.32 \pm 0.76 \mathrm{a}$ \\
\hline $50: 50$ & $4.539 \pm 0.027 \mathrm{a}$ & $0.45 \pm 0.01 \mathrm{~d}$ & $5.12 \pm 1.02 \mathrm{a}$ \\
\hline
\end{tabular}

Note: Values with different superscript in the same column indicated significantly different at $\alpha=5 \%$. 
Table 2: Sensory characteristics of soy corn yogurt with different ratio of soybean and sweet corn.

\begin{tabular}{|l|l|l|l|l|}
\hline Soybean : sweet corn & Appearance & Aroma & Texture & Taste \\
\hline $100: 0$ & $3.6 \pm 1.5^{\mathrm{a}}$ & $3.0 \pm 1.2^{\mathrm{a}}$ & $3.8 \pm 1.3^{\mathrm{a}}$ & $3.9 \pm 1.4^{\mathrm{a}}$ \\
\hline $90: 10$ & $4.2 \pm 1.5^{\mathrm{bc}}$ & $4.0 \pm 1.2^{\mathrm{bc}}$ & $4.0 \pm 1.3^{\mathrm{ab}}$ & $4.0 \pm 1.3^{\mathrm{a}}$ \\
\hline $80: 20$ & $4.1 \pm 1.2^{\mathrm{b}}$ & $3.8 \pm 1.2^{\mathrm{b}}$ & $4.1 \pm 1.4^{\mathrm{ab}}$ & $4.5 \pm 1.3^{\mathrm{b}}$ \\
\hline $70: 30$ & $4.4 \pm 1.4^{\mathrm{bc}}$ & $3.9 \pm 1.2^{\mathrm{bc}}$ & $4.3 \pm 1.4^{\mathrm{b}}$ & $4.0 \pm 1.3^{\mathrm{a}}$ \\
\hline $60: 40$ & $4.4 \pm 1.3^{\mathrm{bc}}$ & $3.9 \pm 1.3^{\mathrm{bc}}$ & $4.1 \pm 1.3^{\mathrm{ab}}$ & $4.1 \pm 1.2^{\mathrm{a}}$ \\
\hline $50: 50$ & $4.6 \pm 1.2^{\mathrm{c}}$ & $4.2 \pm 1.3^{\mathrm{c}}$ & $4.2 \pm 1.4^{\mathrm{b}}$ & $3.9 \pm 1.3^{\mathrm{a}}$ \\
\hline
\end{tabular}

Note: Values with different superscript in the same column indicated significantly different at $\alpha=5 \%$.

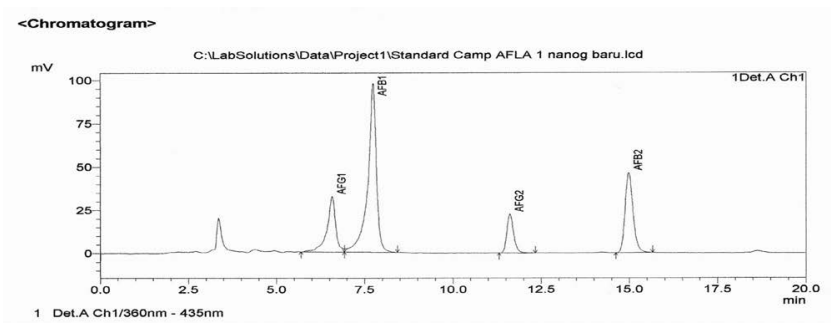

Figure 3: Chromatogram of Standard: $A F G_{1}$, Aflatoxin $G_{1} ; A F B_{1}$, Aflatoxin $B_{1}$; $A F G_{2}$, Aflatoxin $G_{2}$; and $A_{F B}$ : Aflatoxin $B_{2}$.

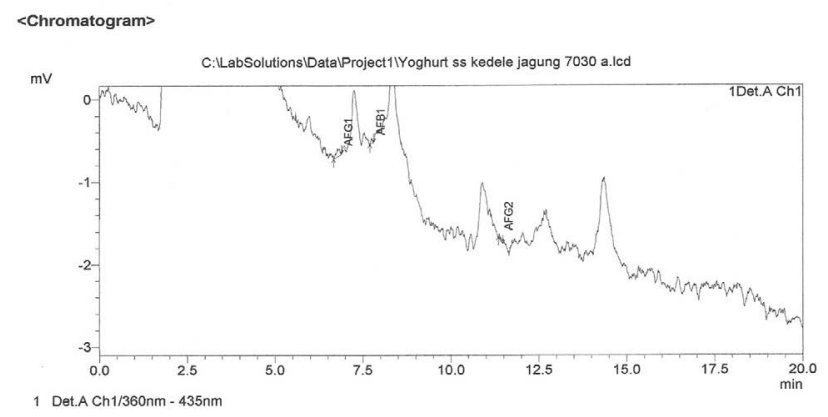

Figure 4: Chromatogram of soy corn yogurt.

statistically the syneresis were not significantly difference at different ratio of soybean and sweet corn. These syneresis levels are higher than those soygurt reported by Estevez et al. [15] which in a range of 1.86\% until $2.87 \%$ which using gelatin as a stabilizer. However, these are lower than flavoured soy yogurt reported by Osundahunsi et al. [16]. This finding reflected that xanthan gum used in this study worked as a good stabilizer to bind and hold the free water in the system. In concerning the syneresis values, it need further study to reduce the syneresis.

\section{Sensory characteristics}

Table 2 showed the result of sensory evaluation of soy corn yogurt with different ratio of soybean and sweet corn.

The overall preference score of all attributes were varied between 3.0 until 4.6. Different ratio of soybean and sweet corn cause significant difference of the preference score of appearance, aroma, texture and taste. Higher sweet corn ratio resulted higher score of appearance and aroma. This might be due to the carotenoid content would provide attractive color of soy corn yogurt. Besides, corn also has some volatile substance such as acetaldehyde which can contribute to reduce beany flavour of soybean. The highest score of appearance and aroma was occured at the ratio of 50:50. Soy corn yogurt at 70:30 ratio of soybean and sweet corn resulted highest score of texture parameter. This might be due to the higher total solids of the soy corn milk. Higher sweet corn ratio would increase total solids of soy corn milk which can contribute to soy corn yogurt's texture become sandy. Soybean and sweet corn ratio of 80:20 resulted the highest score of taste. At 80:20 ratio sour taste of yogurt and sweet taste from sugar were balance.

Based on the sensory properties, soy corn yogurt with 50:50 ratio of soybean and sweet corn is the most acceptable. At this ratio, the soy corn yogurt has total LAB of $6.37 \times 10^{10} \mathrm{cfu} / \mathrm{mL}, \mathrm{pH}$ of 4.539 , acidity of $0.45 \%$, syneresis of $5.12 \%$, while preference score for appearance, aroma, texture and taste were 4.6, 4.2, 4.2 and 3.9, respectively. The scores were categorized in neutral and likely enough. It need further study to improve the sensory characteristics of the soy corn yogurt.

\section{Aflatoxin content in soy corn yogurt}

Figure 3 and 4 showed the chromatograms of standard and soy corn yogurt sample, respectively. Figure 3 showed peaks of aflatoxin $G_{1}, B_{1}, G_{2}$ and $B_{2}$ appeared at retention time of $6.627 ; 7.781 ; 11.738$; and 15.151 minutes, respectively. Figure 4 showed that aflatoxin $G_{1}, B_{1}, G_{2}$ and $\mathrm{B}_{2}$ were not detected in the soy corn yogurt. It mean that the soy corn yogurt was safe food. In concerning the health issue to control the aflatoxin exposure, we recommend that no limitation amount to consume the soy corn yogurt as a health food. It is potential to scale up the soy corn yogurt production commercially.

\section{Conclusions}

The characteristics of soy corn yogurt at various ratios of soybean and sweet corn showed that the soy corn milk is the suitable medium for the lactic acid bacteria. Soybean and sweet corn ratio of 50:50 produced soy corn yogurt with the highest preference score. It need further study to improve the sensory characteristics and to reduce the syneresis value. In concerning the health issue to control the aflatoxin, the soy corn yogurt is categorized as a safe food product. The soy corn milk is potential to be further developed and commercialized as an alternative health food for who lactose intolerance.

\section{References}

1. Omueti O, Ajomale K (2005) Chemical and sensory attributes of soy-corn milk types. Afr J Biotechnol 4: 847-851.

2. Azima RYF, Yani IE (2007) Evaluation of nutritional value and quality of soymilk powder enriched with corn protein concentrate. Proceeding of National Seminar PATPI, Bandung, Indonesia.

3. Kolapo AL, Oladimeji GR (2008) Production and quality evaluation of soy corn milk. J Appl Biosci 1: 40-45.

4. Omueti O, Oguntona EB, Jaiyeola O, Ashaye, OA (2000) Nutritional evaluation of home-level prepared soycorn milk: a protein beverage. Nutr and Food Sci 30: 128-132.

5. Srianta I, Kuswardani I, Tanur AE, Anita F, Lini V (2010) Development of low aflatoxin soy corn yogurt: optimization of soybean and sweet corn ratio and its stability during storage. IJFNPH 3: 161-170.

6. Stoloff L, Francis OJ Jr (1980) Survey for aflatoxins and Zearalenone in canned and frozen sweet corn. J Assoc Off Anal Chem 63: 180-181.

7. Candlish A, Aidoo K, Smith J, Pearson S (2000) A limited survey of aflatoxins and fumonisins in retail maizebased products in the UK using immunoassay detection. Mycotoxin Res 16: 2-8.

8. Trindade CS, Terzi SC, Trugo LC, Della Modesta RC, Couri S (2001) Development and sensory evaluation of soy milk based yoghurt. Arch Latinoam Nutr 51: 100-104.

9. Supavititpatana P, Wirjantoro TI, Raviyan P (2010) Characteristics and shelflife of corn milk yogurt. CMU J Nat Sci 9: 133-150. 
10. Akoma O, Elekwa UO, Afodunrinbi AT, Onyeukwu GC (2000) Yogurt from coconut and tigernuts. JFTA 5: 132-134.

11. Makanjuola OM (2012) Production and Quality Evaluation of Soy-Corn Yoghurt. Advance Journal of Food Science and Technology 4: 130-134.

12. Andrews WH (1994) Update on validation of microbiological methods by AOAC International. J AOAC Int 77: 925-931.

13. Supavititpatana $P$, Wirjantoro TI, Apichartsrangkoon A, Raviyan $P$ (2007) Addition of gelatin enhanced gelation of corn-milk yogurt. Food Chem 106 211-216.
14. Kuswardani I (2010) Nutraceuticals, Functional Foods and Dietary Supplements: Science, Methodologies and Applications: Usage of frozen stock cultures in skim milk added coconut water medium for yogurt production. ISNFF Annual Conference, Bali, Indonesia.

15. Estevez AM, Mejia J, Figuerola F, Escobar B (2008) Effect of solid content and sugar combinations on the quality of soymilk-based yogurt. J Food Process Pres 34: 87-97.

16. Osundahunsi OF, Amosu D, Ifesan BOT (2007) Quality evaluation and acceptibility of soy-yoghurt with different colours and fruit flavours. American Journal of Food Technology 2: 273-280.

\section{Author Affiliation}

${ }^{1}$ Department of Food Technology, Widya Mandala Catholic University Surabaya, Indonesia

Submit your next manuscript and get advantages of SciTechnol submissions

* 50 Journals

* 21 Day rapid review process

* 1000 Editorial team

* 2 Million readers

* Publication immediately after acceptance

* Quality and quick editorial, review processing

Submit your next manuscript at • www.scitechnol.com/submission 